Research Paper

\title{
Curcumin Enhances the Anticancer Effect Of 5-fluorouracil against Gastric Cancer through Down-Regulation of COX-2 and NF- KB Signaling Pathways
}

\author{
Hongru Yang1, 2, Shaoqiu Huang3 3 , Yumeng $\mathrm{Wei}^{3}$, Shousong $\mathrm{Cao}^{4}$, Chao $\mathrm{Pi}^{3}$, Ting Feng 3 , Jing Liang3 ${ }^{3}$ Ling \\ Zhao $^{3 凶}$, Guosheng Ren ${ }^{1 凶}$ \\ 1. The First Affiliated Hospital of Chongqing Medical University, No.1 Yixue Road, Yuzhong District, Chongqing 400016, China; \\ 2. The Affiliated Hospital of Southwest Medical University, No.5 Taiping Street, Jiangyang District, Luzhou , Sichuan 646099, China; \\ 3. Department of Pharmaceutics, School of Pharmacy, Southwest Medical University, No.3-5, Zhongshan Road, Jiangyang District, Luzhou, Sichuan 646000, \\ China; \\ 4. Department of Pharmacology, School of Pharmacy, Southwest Medical University, No.3-5, Zhongshan Road, Jiangyang District, Luzhou, Sichuan 646000, \\ China.
}

$\square$ Corresponding authors: Guosheng Ren, The First Affiliated Hospital of Chongqing Medical University, No.1 Yixue Road, Yuzhong District, Chongqing 400016, China. Tel: +86 2389012505; Fax: +86 2389012505; E-mail address: rgs726@163.com. Ling Zhao, zhaoling-998@163.com.

(c) Ivyspring International Publisher. This is an open access article distributed under the terms of the Creative Commons Attribution (CC BY-NC) license (https:// creativecommons.org/licenses/by-nc/4.0/). See http://ivyspring.com/terms for full terms and conditions.

Received: 2017.03.21; Accepted: 2017.08.22; Published: 2017.10.17

\begin{abstract}
Background: 5-fluorouracil (5-FU) is one of the most commonly used first-line anticancer drugs to treat gastric cancer in clinical practice. However, severe adverse events such as gastrointestinal toxicity and bone marrow suppression limit its clinical application. Combination chemotherapy to combine two or more anticancer drugs with different mechanistic action is an effective anticancer strategy against gastric cancer. Therefore, we studied the anticancer effect of the combination of 5 -FU with curcumin against gastric cancer MKN45 and AGS cells (normal gastric mucosal GES-1 cells as control) and associated molecular mechanisms.

Methods: Cytotoxicity of 5-FU and curcumin alone or in combination was evaluated in MKN45, AGS and GES cells by MTT assay. The protein expressions of COX-2 and NF-KB were evaluated in MKN45 cells by Western blotting analysis. In addition, antitumor activity of 5-FU and curcumin alone or in combination was evaluated in nude mice bearing MKN45 tumor xenografts in vivo.

Results: The combination of 5-FU and curcumin (2:1, mol/mol) showed 2.2-, 3.5-fold and 2.3-, 3.9-fold enhanced cytotoxic effect compared to 5-FU or curcumin alone and generated synergistic effect at the concentration of 5-FU $(>4.09$ and $>5.71 \mu \mathrm{mol} / \mathrm{l})$ and curcumin $(>2.05$ and $>2.86$ $\mu \mathrm{mol} / \mathrm{l})$ in MKN45 cells for $48 \mathrm{~h}$ and $72 \mathrm{~h}$ exposures, respectively. The combination of 5-FU and curcumin also potentiated cytotoxicity in AGS cells compared to 5-FU or curcumin alone but the effect was moderate. However, the cytotoxicity of 5 -FU and curcumin alone or in combination was much less in GES-1 cells. Furthermore, the protein expressions of COX-2 and NF-KB in MKN45 cells were decreased by $44.79 \%$ and $37.67 \%, 47.17 \%$ and $48.21 \%, 60.21 \%$ and $62.44 \%$, respectively, after treatment of curcumin $(25 \mu \mathrm{mol} / \mathrm{l})$ and 5 -FU $(50 \mu \mathrm{mol} / \mathrm{l})$ alone or in combination for $48 \mathrm{~h}$. Curcumin also enhanced the anticancer activity of 5-FU without increasing toxicity in nude mice bearing MKN45 tumor xenografts in vivo.

Conclusions: Curcumin enhances the anticancer effect of 5-FU against gastric cancer in vitro and in vivo. The possible molecular mechanism may be, at least in part, related to down-regulation of COX-2 and NF-KB pathways.
\end{abstract}

Key words: 5-fluorouracil, curcumin, gastric cancer, MKN45 cell, COX-2, NF-кB. 


\section{Introduction}

Gastric cancer is the fourth most common cancer and the second-third most common cause of cancer death worldwide [1,2]. Asian countries are not only with a high incidence of gastric cancer, but also with a lower rate of five-year survival due to lack of early diagnosis and radical resection $[3,4]$. Therefore, it is necessary to find novel and more effective chemotherapeutic agents and/or combination regimens for the treatment of gastric cancer to prolong the survival of the patients.

5-fluorouracil (5-FU) is a wildly used first-line chemotherapeutic drug for gastric cancer treatment, but many patients are insensitive in response to 5-FU-based treatment, which resulted in poor efficacy. Recently, a study reported that the combination of natural compound icariin with 5-FU could increase the efficacy and reduce toxicity of 5-FU in a murine model of colorectal cancer [5]. Curcumin is a kind of yellow phenolic pigment isolated from turmeric rhizome with many pharmacological effects, such as antitumor, antioxidant and anti-inflammation etc. [6]. In recent years, the antitumor effect and associated mechanism(s) of curcumin have been extensively studied. Researchers have found that curcumin has advantages over traditional chemotherapeutic drugs, including wide anticancer spectrum, less toxic side effect and so on $[7,8]$. It has been reported that curcumin has a significant inhibitory effect on the proliferation of certain types of gastric cancer cells by targeting multiple potent molecular singling pathways including COX-2 and NF-kB [9]. COX-2 is a kind of inducible enzyme and it is overexpressed in gastric cancer cells but its expression is none or very low in normal gastric mucosa. Study has showed that overexpression of COX-2 occurred in approximately $50 \%-80 \%$ of patients with gastric cancer [10]. It was suggested that the overexpression of COX-2 may be related to the development and progression of gastric cancer through multiple factors such as apoptosis inhibition, immune suppression, and promotion of angiogenesis and tumor invasion [11]. Previous studies have demonstrated that COX-2 inhibitors could inhibit the occurrence of gastric precancerous lesions by inhibiting the cell growth and inducing apoptosis in gastric cancer cells $[12,13]$. It provides a new approach for the treatment of gastric cancer and targeted therapy. Nuclear transcription factor (NF-KB) is a class of proteins that can combine with a fixed nucleotide sequence in the promoter region of certain genes to initiate transcription of the gene [14]. Recent studies have shown that activation of NF-KB signaling pathway plays an important role in the development of gastric cancer $[15,16]$. It was generally believed that the expressions of COX-2 and NF-kB were higher in gastric cancer tissues in comparison with the normal gastric mucosa [17]. Therefore, the inhibitors of COX-2 and NF-KB may be effective in the treatment of gastric cancer.

Numerous studies have found that the combination of 5-FU and curcumin significantly improved anticancer effectiveness against breast and colon cancers in vitro and in vivo [18-21]. However, there are only limited studies on the anticancer effect and associated mechanism of 5-FU in combination with curcumin against gastric cancer. In the present study, we investigated the inhibitory effect in vitro against gastric cancer MKN45 and AGS cells (normal gastric mucosal GES-1 cells as control) and the antitumor activity in vivo against gastric cancer MKN45 tumor xenograft as well as associated mechanism of the combination of curcumin and 5-FU in order to provide the scientific rationale for clinical application in the treatment of gastric cancer.

\section{Material and Methods}

\section{Materials}

Curcumin (purity $\geq 98 \%$ ), 5-FU, RPMI 1640 medium, fetal calf serum, $0.25 \%$ trypsin, and 100 units/ $\mathrm{ml}$ of penicillin-streptomycin, 3-(4,5-dime-thyl2-thiazolyl)-2,5-diphenyl-2-H-tetrazolium bromide (MTT), dimethyl sulfoxide (DMSO) were purchased from Luzhou Shuangjiang Chemical Co, Ltd (Luzhou, Sichuan, China). NF-kB p65 antibody, COX-2 antibody and $\beta$-action were purchased from Luzhou ShenrongJia Experimental Co, Ltd (Luzhou, Sichuan, China).

\section{Cell line and cell culture}

Human gastric cancer cells MKN45 and AGS and normal gastric mucosal cells GES-1 were purchased from China Center for Type Culture Collection (CCTCC, Wuhan, Hubei, China). The cells were cultured in RPMI 1640 medium supplemented with $10 \%$ fetal calf serum and $1 \%$ penicillin-streptomycin, and incubated with saturated humidity in $5 \% \mathrm{CO}_{2}$ at $37^{\circ} \mathrm{C}$.

\section{Cell growth inhibition assay}

The MTT assay was used for cell growth inhibition evaluation. Cells ( $90 \%$ confluence) were seeded at $5 \times 10^{3}$ cells/well into 96-well plates. After being cultured for $24 \mathrm{~h}$, the cells were treated with various concentrations of 5-FU $(6.25,12.5,25.0,50.0$, and $100.0 \mu \mathrm{mol} / \mathrm{l})$ and curcumin $(3.125,6.25,12.5,25.0$ 
and $50.0 \mu \mathrm{mol} / \mathrm{l})$ alone or in combination (2:1 ratio, $\mathrm{mol} / \mathrm{mol}$ ) for $48 \mathrm{~h}$ and $72 \mathrm{~h}$, respectively; and same volume of solvent was used as vehicle control. Then, $20 \mu \mathrm{l}$ of MTT $(5 \mathrm{mg} / \mathrm{ml})$ were added to each well and the cells were incubated for another $4 \mathrm{~h}$ at $37^{\circ} \mathrm{C}$ in the dark. The aliquots were removed and the remaining crystals (formazan precipitates) were solubilized with $150 \mu \mathrm{l}$ of DMSO and the cells were incubated for an additional $10 \mathrm{~min}$ at $37^{\circ} \mathrm{C}$ with gentle shaking before the measurement of the absorbance (OD) at $490 \mathrm{~nm}$ using an enzyme-linked immunosorbent assay. All the samples were performed in triplicate. The selections of the concentrations with curcumin and 5 -FU in our studies were based on previous reports of similar studies from the literature $[22,23]$.

\section{Median-effect concentration $\left(\mathrm{IC}_{50}\right)$ calculation and synergistic effect assessment for the combination of 5-FU and curcumin}

The cell growth inhibitory rate (\%) was calculated as following formula:

$$
\begin{gathered}
\text { Inhibitory rate }(\%)=\left(\mathrm{OD}_{\text {control- }} \mathrm{OD}_{\text {treated }}\right) / \mathrm{OD}_{\text {control }} \times \\
100 \%
\end{gathered}
$$

The calculation of $\mathrm{IC}_{50}$ of drugs alone and in combination was based following equation as previously described by Chou et al. [24, 25].

$$
\begin{gathered}
\frac{F a}{1-F a}=\left(\frac{D}{D_{m}}\right)^{m} \\
\mathrm{Fa}=1-\mathrm{OD}_{\text {treatment }} / \mathrm{OD}_{\text {control }}
\end{gathered}
$$

$\mathrm{Fa}$ is the affected fraction (effect), D is the drug concentration, $\mathrm{D}_{\mathrm{m}}$ is the medium-effect concentration, and $\mathrm{m}$ is the slope of the mid-efficiency curve. The combined index $(\mathrm{CI})$ of combined drugs with different effects was calculated as following formula: $\mathrm{CI}=\left(\mathrm{D}_{2} /\right.$ $\left.D_{\chi 2}\right)+\left(D_{1} / D_{\chi 1}\right)+\alpha\left(D_{1} / D_{2} / D_{\chi 1} D_{\chi 2}\right)$, where $D_{\chi 1}$ and $\mathrm{D}_{\chi_{2}}$ in the formula are the inhibitory concentrations of curcumin and 5-FU alone, while $\mathrm{D}_{1}$ and $\mathrm{D}_{2}$ are the inhibitory concentrations of the combination of curcumin and 5-FU. $a=0$ or $=1$ depends on whether the two drugs acted as mutually non-exclusive or mutually exclusive. It indicates antagonism effect when $\mathrm{CI}>1$; additive effect when $\mathrm{CI}=1$; and synergistic effect when $\mathrm{CI}<1$.

\section{Western blotting analysis of the protein expressions of COX-2 and NF-KB in MKN45 cells in vitro}

Cells ( $\sim 90 \%$ confluence) were seeded at $5 \times 10^{5}$ cells/plate on 6-well plates, then, incubated for $24 \mathrm{~h}$ and treated with curcumin $(25 \mu \mathrm{mol} / \mathrm{l})$ and 5-FU (50 $\mu \mathrm{mol} / \mathrm{l}$ ) alone or in combination (an additional group of $12.5 \mu \mathrm{mol} / 1$ curcumin $+25 \mu \mathrm{mol} / 15$-FU for the combination) for $48 \mathrm{~h}$, while RPMI1640 medium containing same concentration of DMSO was used as vehicle control. Then, the culture media were discarded and the cells were washed with cold PBS buffer twice for harvest. Cell pellets were disrupted in cell RIPA buffer $(0.5 \%$ NP-40, $50 \mathrm{mM}$ Tris- $\mathrm{HCl}, 120$ $\mathrm{mM} \mathrm{NaCl}, 1 \mathrm{mM}$ EDTA, 0.1 $\mathrm{mM} \mathrm{Na}_{3} \mathrm{VO}_{4}, 1 \mathrm{mM} \mathrm{NaF}, 1$ $\mathrm{mM}$ PMSF, and $1 \mu \mathrm{g} / \mathrm{ml}$ leupeptin, $\mathrm{pH} 7.5$ ) and collected after centrifuging at $800 \times \mathrm{g}$ for $5 \mathrm{~min}$ at $4{ }^{\circ} \mathrm{C}$, and the lysates were centrifuged at $9600 \times \mathrm{g}$ for $15 \mathrm{~min}$ at $4{ }^{\circ} \mathrm{C}$ to collect the cytoplasmic and nuclear proteins, respectively. The protein concentrations were determined by phenyl methane sulfonyl fluoride (PMSF) method.

Protein samples ( $30 \mu \mathrm{l}$ each) were loaded on $12 \%$ sodium dodecyl sulfate- polyacrylamide gels and separated with electrophoresis and subsequently transferred onto PVDF membranes. Non-specific binding was blocked with $5 \%$ milk in TBST [ $5 \mathrm{mmol} / 1$ Tris- $\mathrm{HCl}, 136 \mathrm{mmol} / 1 \mathrm{NaCl}$, and $0.1 \%$ Tween-20, $\mathrm{pH}$ 7.6] for $1 \mathrm{~h}$. The membranes were cultured with primary antibodies against COX-2 (1:1000), NF-KB $(1: 1000)$ or $\beta$-actin $(1: 800)$ overnight at $4^{\circ} \mathrm{C}$. Then the membranes were washed three times with $1 \times$ TBST, followed by incubating with secondary antibodies (1:1000 dilution) at room temperature for $1 \mathrm{~h}$ and washed three times with $1 \times$ TBST. Protein bands were visualized using an ECL system. Quantity One software (Bio-Rad Laboratories, Hercules, CA, USA) was used to analyze the grayscale values of the bands.

\section{Experimental animals}

Six-to-eight-week old SPF grade female athymic nude mice (nu/nu, body weight 18-20 g) were obtained from Chengdu Dossy Experimental Animals Co., Ltd (Chengdu, Sichuan, China, Certificate No. SCXK2015-030). The mice were housed up to five mice per cage in sterile plastic cages with free access to water and food ad libitum in a controlled room temperature $\left(22 \pm 1{ }^{\circ} \mathrm{C}\right)$, humidity $(50-70 \%)$ with a 12-h light/dark cycle. All animal experiments were performed strictly according to university guideline and followed to an approved protocol (Permit No. 2015DW040) by the Committee on Use and Care of Animals of Southwest Medical University (Luzhou, Sichuan, China). There were 8 mice for each experimental group.

\section{Establishment of nude mouse model of tumor xenograft and drug treatment}

Human gastric cancer MKN45 tumor xenografts were established in nude mice from cultured MKN45 cells by inoculating subcutaneously (s.c.) $0.2 \mathrm{ml}$ of cell suspension $\left(1.0 \times 10^{8}\right.$ cells $\left./ \mathrm{ml}\right)$ in the right flank of the mice. Treatment was initiated 10 days later when the 
tumors reached $\sim 100 \mathrm{~mm}^{3}(\mathrm{mg})$. Thirty two nude mice bearing MKN45 tumor xenografts with similar tumor size were selected and randomly divided into four groups with 8 mice for each group: 1 . Control, $0.2 \mathrm{ml}$ of normal saline solution; 2. 5-FU $52 \mathrm{mg} / \mathrm{kg}$; 3 . curcumin $74 \mathrm{mg} / \mathrm{kg}$; and 4. 5-FU $52 \mathrm{mg} / \mathrm{kg}+$ curcumin $74 \mathrm{mg} / \mathrm{kg}$. Treatments were given by intraperitoneal (i.p.) administration every three days (day $0,3,6,9,12$, and 15) for 6 times in total. The body weights of mice were recorded every 3 days and tumor volumes were determined at the same time by a vernier caliper to measure two axes of the tumor $(\mathrm{L}$, longest axis; $\mathrm{W}$, shortest axis). Tumor volume $\left(\mathrm{mm}^{3}\right)$ or weight $(\mathrm{mg})$ was calculated according to the formula of $0.5 \times$ length $\times$ width $^{2}$. On the 18 th day, the mice were sacrificed when tumors in control group reached $\sim 1.0 \mathrm{~cm}^{3}(1,000 \mathrm{mg})$ in size. The tumor was separated from each mouse and weighed. Antitumor activity was assessed by tumor growth inhibition (TGI), which is mean tumor weight (MTW) of the treated group (TG) relative to the saline-treated control group (CG) on day 18, as calculated according to the formula: (MTWTG-MTWCG) $\div$ MTWCG $\times$ $100 \%$ as previously described [26].

\section{Statistical analysis}

All data were expressed as mean \pm standard deviation (SD). Statistical differences of the data were analyzed by Student's t-test and/or one-way univariate analysis of variance (ANOVA). A difference at $P<0.05$ was considered to be statistically significant (marked as *). IBM SPSS statistics software version 18.0 (SPSS Company, Chicago, IL, USA) was used for the statistical analysis.

\section{Results}

\section{Effect of 5-FU and curcumin alone or in combination on cell growth inhibition in gastric cancer MKN45 and AGS cells and normal gastric mucosal GES- 1 cells by MTT assay}

First, we evaluated the inhibitory effect of 5-FU and curcumin alone or in combination with various concentrations in gastric cancer MKN45 and AGS cells and compared to normal gastric mucosal GES-1 cells after $48 \mathrm{~h}$ and $72 \mathrm{~h}$ treatment and the results are shown in Figure 1. The data showed that 5-FU and curcumin alone or in combination significantly inhibited cells growth of gastric cancer MKN45 and AGS cells in a time- and concentration-dependent manner, while MKN45 cells were more sensitive response to drug treatment than that of AGS cells. Interesting, curcumin has greater cytotoxicity than 5-FU (Figures 1A \& 1B) but the combination of 5-FU and curcumin showed potent inhibitory effect than 5-FU and curcumin alone (Figure 1C) against MKN45 and AGS cells. However, the cytotoxicity was much less in normal gastric mucosal GES-1 cells by the treatment of curcumin and 5-FU alone or in combination. The results suggested that GES-1 cells was relatively resistant to the treatment of curcumin and 5-FU and the combination may selectively target gastric cancer cells to improve therapeutic efficacy and reduce side effect of 5-FU and curcumin against normal cells.

\section{Combination effect of 5-FU and curcumin on cytotoxicity in gastric cancer MKN45 and AGS cells and normal gastric mucosal GES-1 cells}

Next, we calculated the combination index (CI) in cell growth inhibition with the combination of 5-FU and curcumin in MKN45, AGS and GES-1 cells to evaluate either mutually synergetic effect or antagonistic effect. As shown in Table 1, the $\mathrm{IC}_{50}$ values of 5 -FU were $70.97 \pm 4.32$ and $38.22 \pm 2.96$ $\mu \mathrm{mol} / 1$ (MKN45 cells); $106.42 \pm 4.38$ and $82.74 \pm 3.55$ $\mu \mathrm{mol} / 1$ (AGS cells); and $199.32 \pm 3.09$ and $178.44 \pm 4.87$ $\mu \mathrm{mol} / 1$ (GES cells) for $48 \mathrm{~h}$ or $72 \mathrm{~h}$ exposure, respectively. The $\mathrm{IC}_{50}$ values of curcumin were $20.66 \pm$ 2.45 and $11.95 \pm 2.13 \mu \mathrm{mol} / 1$ (MKN45 cells); $29.94 \pm$ 2.36 and $25.57 \pm 1.93 \mu \mathrm{mol} / 1$ (AGS cells); and $90.01 \pm$ 3.19 and $83.41 \pm 2.36 \mu \mathrm{mol} / 1$ (GES cells) for $48 \mathrm{~h}$ or 72 $\mathrm{h}$ exposure, respectively. The $\mathrm{IC}_{50}$ values of the combination of 5-FU and curcumin (2:1 ratio, $\mathrm{mol} / \mathrm{mol}$ ) were $18.02 \pm 1.42$ and $10.77 \pm 1.34 \mu \mathrm{mol} / 1$ for 5-FU, $9.01 \pm 1.30$ and $5.38 \pm 1.05 \mu \mathrm{mol} / 1$ for curcumin (MKN45 cells), $30.86 \pm 2.87$ and $25.94 \pm 1.08$ $\mu \mathrm{mol} / 1$ for 5 -FU, $15.43 \pm 1.42$ and $12.97 \pm 1.36 \mu \mathrm{mol} / 1$ for curcumin (AGS cells); $83.14 \pm 2.72$ and $76.88 \pm 2.40$ $\mu \mathrm{mol} / \mathrm{l}$ for 5 -FU, $41.57 \pm 1.21$ and $38.44 \pm 1.89 \mu \mathrm{mol} / 1$ for curcumin (GES cells) for $48 \mathrm{~h}$ or $72 \mathrm{~h}$ exposure, respectively. Thus, curcumin in combination with 5-FU markedly enhanced cytotoxicity than 5-FU and curcumin alone for $48 \mathrm{~h}$ and $72 \mathrm{~h}$ in all three cell lines with statistically significant difference $(P<0.05)$. The data suggested that the cell growth inhibition by 5-FU and curcumin were concentration- and timedependent in MKN45 cells but less dependent in AGS and GES-1 cells (Table 1).

Table 1. The $\mathrm{IC}_{50}$ values of $5-\mathrm{FU}$ and curcumin alone and in combination.

\begin{tabular}{llllll}
\hline Cells & Drugs & $48 \mathrm{~h}(\mu \mathrm{mol} / \mathrm{l})$ & $72 \mathrm{~h}(\mu \mathrm{mol} / \mathrm{l})$ \\
\hline & & Drug alone & Combination & Drug alone & Combination \\
\hline MNK45 & 5-FU & $70.97 \pm 4.32$ & $18.02 \pm 1.42$ & $38.22 \pm 2.96$ & $10.77 \pm 1.34$ \\
cells & Curcumin & $20.66 \pm 2.45$ & $9.01 \pm 1.30$ & $11.95 \pm 2.13$ & $5.38 \pm 1.05$ \\
AGS & 5-FU & $106.42 \pm 4.38$ & $30.86 \pm 2.87$ & $82.74 \pm 3.55$ & $25.94 \pm 1.08$ \\
cells & Curcumin & $29.94 \pm 2.36$ & $15.43 \pm 1.42$ & $25.57 \pm 1.93$ & $12.97 \pm 1.36$ \\
GES-1 & 5-FU & $199.32 \pm 3.09$ & $83.14 \pm 2.72$ & $178.44 \pm 4.87$ & $76.88 \pm 2.40$ \\
cells & Curcumin & $90.01 \pm 3.19$ & $41.57 \pm 1.21$ & $83.41 \pm 2.36$ & $38.44 \pm 1.89$
\end{tabular}



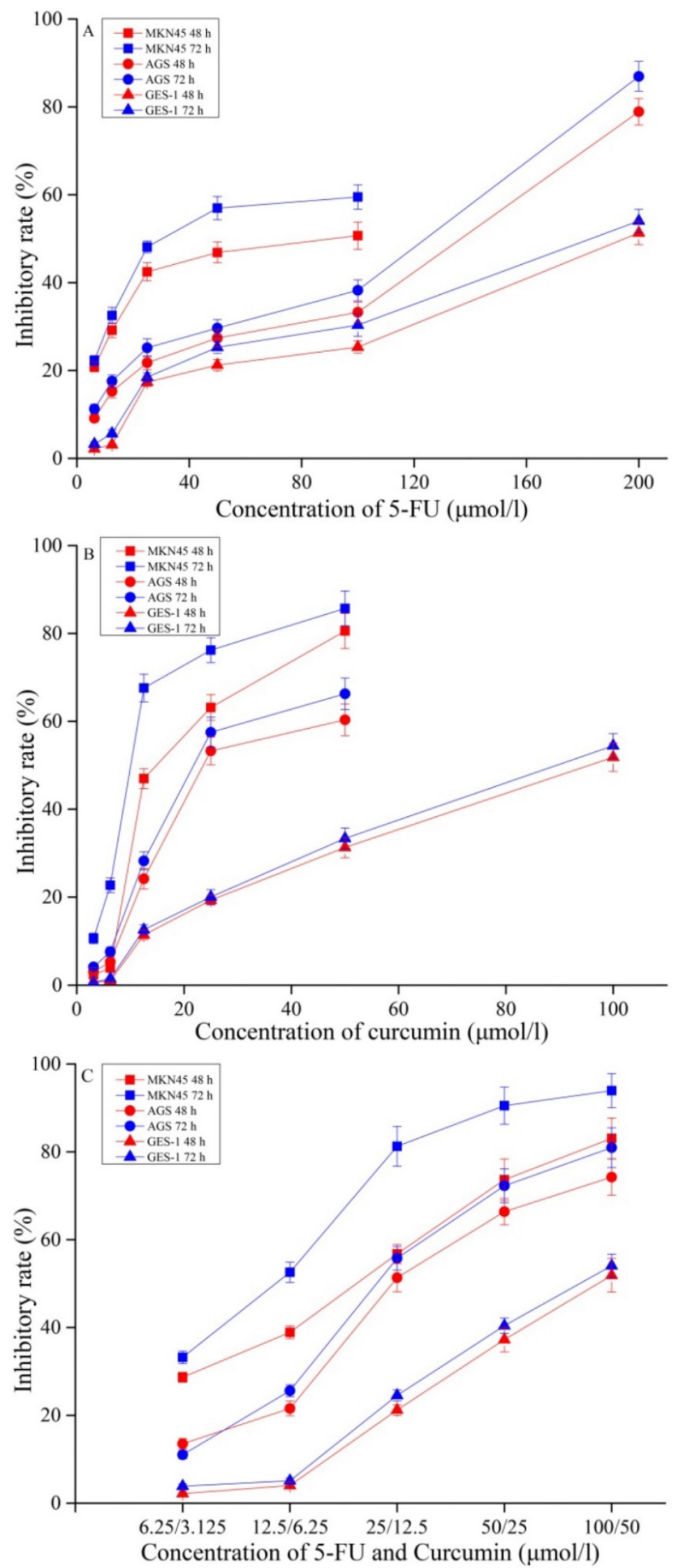

Figure 1. Inhibitory effects of 5-FU (A), and curcumin (B) alone or in combination (C) on MKN45, AGS and GES-1 cells for $48 \mathrm{~h}$ or $72 \mathrm{~h}$ incubation. The results are representative of at least three independent experiments run in triplicate. 
As shown in Figure 2, the combination of 5-FU and curcumin exhibited a synergetic effect on MKN45 cells for $48 \mathrm{~h}$ drug exposure with the Fa value was more than $0.2(\mathrm{CI}<1)$. Therefore, the combination of 5 -FU and curcumin displayed a synergetic effect when the concentration of 5-FU was greater than 4.09 $\mu \mathrm{mol} / 1$ and curcumin was greater than $2.05 \mu \mathrm{mol} / 1$. Similarly, for $72 \mathrm{~h}$ drug exposure, the combination of 5-FU and curcumin also exhibited a synergetic effect with the Fa value was more than $0.3(\mathrm{CI}<1)$, when the concentration of 5 -FU was higher than $5.71 \mu \mathrm{mol} / 1$ and curcumin was higher than $2.86 \mu \mathrm{mol} / 1$.

The combination of 5-FU and curcumin also showed a synergetic effect on AGS cells for $48 \mathrm{~h}$ and $72 \mathrm{~h}$ drug exposure with the Fa values as more than $0.1(\mathrm{CI}<1)$ when the concentration of 5 -FU was greater than 4.38 and $4.84 \mu \mathrm{mol} / 1$, and curcumin was greater than 2.19 and $2.42 \mu \mathrm{mol} / \mathrm{l}$.

Similarly, The combination of 5-FU and curcumin exhibited a synergetic effect on GES-1 cells for $48 \mathrm{~h}$ and $72 \mathrm{~h}$ drug exposure with the Fa values as more than 0.2 and $0.1(\mathrm{CI}<1)$, respectively; when the concentration of 5-FU was greater than 29.62 and $13.34 \mu \mathrm{mol} / 1$ and curcumin was greater than 14.81 and $6.67 \mu \mathrm{mol} / \mathrm{l}$. The data indicated that higher concentration of 5-FU and curcumin were needed in order to achieve synergetic effect in normal gastric mucosal GES-1 cells than that of gastric cancer MKN45 and AGS cells.

\section{Effect of 5-FU and curcumin alone or in combination on the protein expressions of COX-2 and NF-KB in MKN45 cells by Western blotting assay}

To examine the effect of 5-FU and curcumin alone or in combination on the protein expressions of COX-2 and NF- $\mathrm{kB}$ for investigation of the possible associated mechanism, we treated MKN45 cells with 5-FU and curcumin alone or in combination for $48 \mathrm{~h}$ and harvested the cells to analyze their protein expressions by Western blotting and the data are summarized in Figure 3. The intensities of protein bands of COX-2, NF- $\mathrm{KB}$ and $\beta$-actin (as control) are shown in Figure 3A. The expression of COX-2 protein was decreased by $44.79 \%, 47.17 \%, 45.82 \%$ and $60.21 \%$ by 5 -FU ( $50 \mu \mathrm{mol} / \mathrm{l})$, curcumin $(25 \mu \mathrm{mol} / \mathrm{l}), 5$-FU ( 25 $\mu \mathrm{mol} / \mathrm{l})+$ curcumin $(12.5 \mu \mathrm{mol} / \mathrm{l})$, or 5 -FU $(50 \mu \mathrm{mol} / \mathrm{l})$ + curcumin $(25 \mu \mathrm{mol})$, respectively; (Figure 3B). The data indicated that the combination at the same concentration was more effective to inhibit COX-2 protein expression than 5-FU and curcumin alone $(P<$ $0.05)$. In addition, the combination of 5-FU and curcumin exhibited a concentration-dependent manner with statistical significance $(P<0.05)$ between the two tested concentrations (Figure 3B).

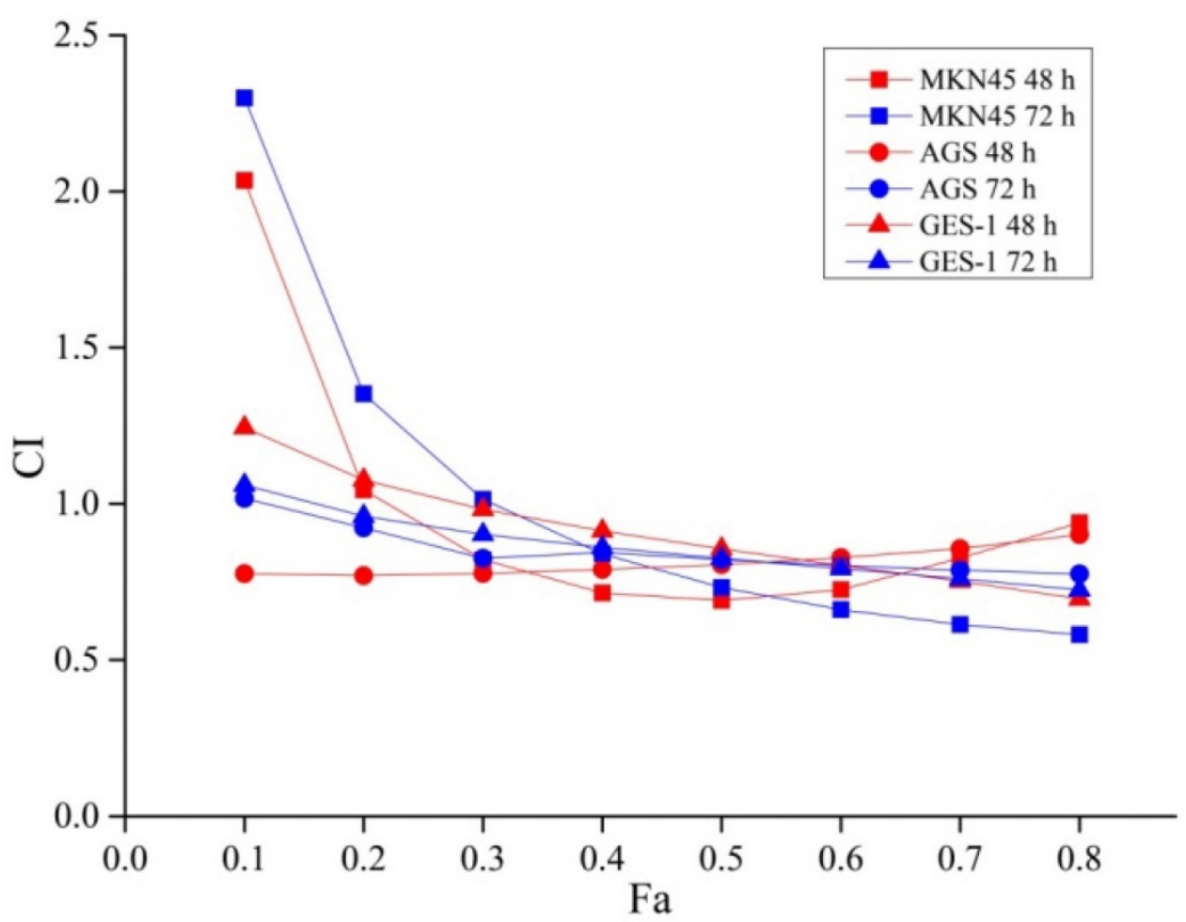

Figure 2. Exponential effect curves of the combination of 5-FU and curcumin in MKN45, AGS and GES-1 cells for $48 \mathrm{~h}$ or $72 \mathrm{~h}$ treatment. Cl: combination index; Fa was the combination effect of two drugs. When $\mathrm{Cl}>1$, antagonist effect; $\mathrm{Cl}=1$, additive effect; and $\mathrm{Cl}<1$, synergistic effect. Each point is corresponding to a $\mathrm{Cl}$ value of different drug combination effects. The results are representative of at least three independent experiments run in triplicate. 


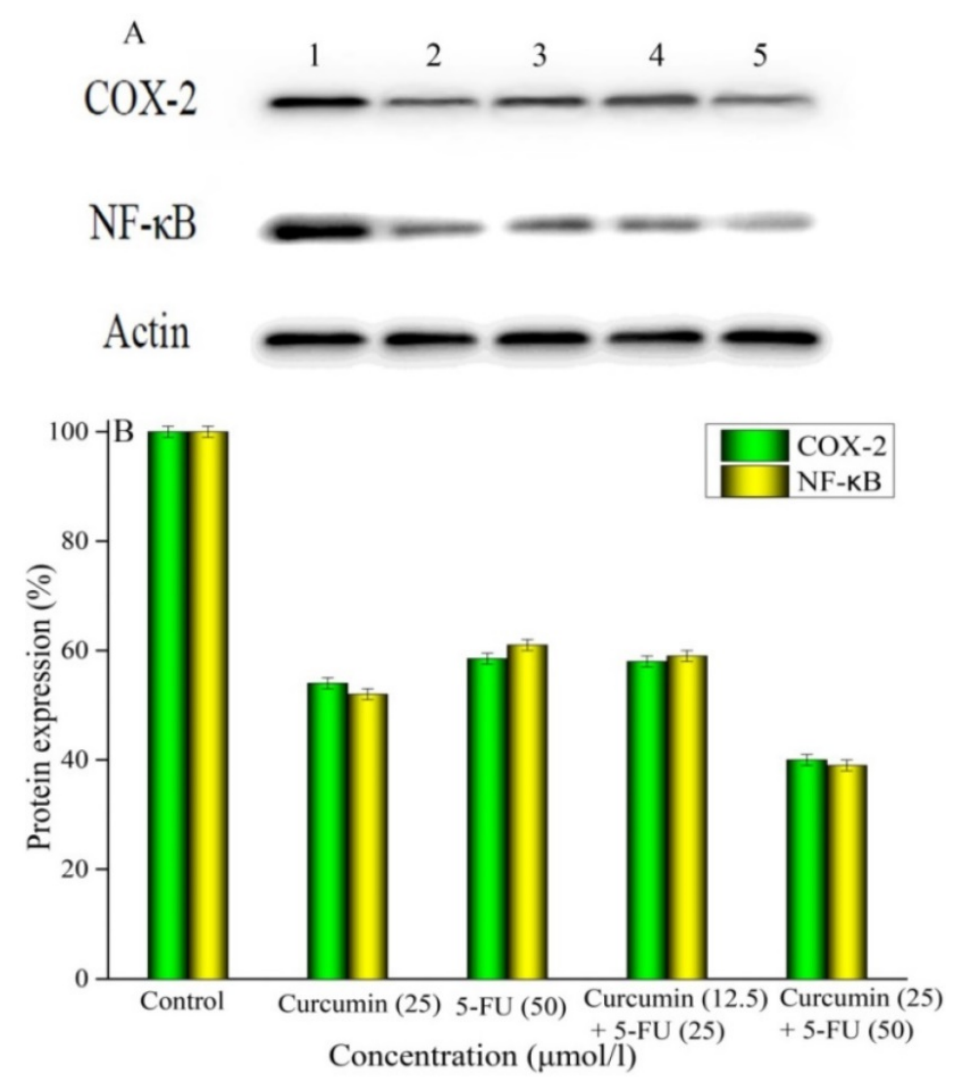

Figure 3. Effects of 5-FU and curcumin alone or in combination on the protein expressions of COX-2 and NF-KB in MKN45 cells by Western blotting analysis. MKN45 cells were treated with 5-FU and curcumin alone or in combination for $48 \mathrm{~h}$. A: Band 1 was COX-2 and NF-KB proteins and $\beta$-actin (control); Band 2 was $25 \mu \mathrm{mol} / \mathrm{l}$ of curcumin; Band 3 was $50 \mu \mathrm{mol} / / \mathrm{l}$ of 5 -FU; Band 4 was $25 \mu \mathrm{mol} / \mathrm{l}$ of 5 -FU $+12.5 \mu \mathrm{mol} / \mathrm{l}$ of curcumin; and band 5 was $50 \mu \mathrm{mol} / \mathrm{l}$ of 5 -FU $+25 \mu \mathrm{mol} / / \mathrm{l}$ of curcumin. B: The ratio of protein expressions of COX-2 and NF-KB. The results are representative of at least three independent experiments run in triplicate and expressed as the mean $\pm \mathrm{SD}$. $* P<0.05$ vs control; $* * P<0.05$ vs 5 -FU and curcumin alone.

Similar results were obtained with the expression of NF-KB protein in MKN45 cells treated with 5-FU and curcumin alone or in combination for $48 \mathrm{~h}$ (Figure 3B). The expression of NF-kB protein was decreased by $37.67 \%, 48.21 \%, 42.35 \%$, and $62.44 \%$ by 5 -FU $(50 \mu \mathrm{mol} / \mathrm{l})$, curcumin $(25 \mu \mathrm{mol} / \mathrm{l}), 5-\mathrm{FU}(25$ $\mu \mathrm{mol})+$ curcumin $(12.5 \mu \mathrm{mol})$, or 5 -FU $(50 \mu \mathrm{mol})+$ curcumin $(25 \mu \mathrm{mol})$, respectively; compared to the control. The data indicated that the combination of 5 -FU and curcumin significantly $(P<0.05)$ inhibited the expression of NF-KB protein compared to the control in a dose-dependent manner, with only the same concentration as that of 5-FU and curcumin alone but not lower concentration was more effective (Figure 3B) than single drug treatment.

\section{Antitumor activity of 5-FU and curcumin alone or in combination against human gastric cancer MKN45 tumor xenograft in vivo}

Next, we further evaluated the in vivo antitumor activity and toxicity of 5-FU and curcumin alone or in combination in nude mice bearing MKN45 tumor xenografts to validate the in vitro findings and the results are shown in Figure 4. The growth of tumor in control mice was relatively fast and reached over 1000 $\left(\mathrm{mm}^{3}\right)$ on day 18 after the initiation of the treatment. 5 -FU at $52 \mathrm{mg} / \mathrm{kg}$ only had moderate effect on tumor growth inhibition. Interestingly, curcumin exhibited greater tumor growth inhibition compared to that of 5-FU. However, the combination of curcumin and 5-FU was the most effective treatment in tumor growth inhibition against MKN45 tumor xenografts (Figure 4A). Meanwhile, the body weight change was similar even gained more weight in the mice treated with the combination of 5-FU and curcumin than that each drug alone during and after treatment (Figure $4 B$ ), indicating that the combination potentiated the antitumor activity but didn't increase toxicity and the dose used did not reach the maximum tolerated dose (MTD) for each drug alone or in combination. Then, the tumor bearing mice were humanely sacrificed because the tumors in control mice grow to near 2000 $\mathrm{mg}$ and the tumor from each mouse was taken and weighed to compare antitumor activity. The weights of tumors reached to $1693 \pm 138 \mathrm{mg}$ on day 18 after initialized treatment ( 28 days after the cancer cells were inoculated in mice). However, the weights of tumors were the smallest $(258 \pm 38 \mathrm{mg})$ with greatest tumor grow inhibition $(84.76 \%)$ in the mice treated with the combination of 5-FU and curcumin 
compared to that of 5-FU (tumor weight: $1235 \pm 105$ $\mathrm{mg}$, inhibitory rate: $27.05 \%$ ) and curcumin (tumor weight: $687 \pm 87 \mathrm{mg}$ ) inhibitory rate: $59.42 \%$ ) alone (Figures 4C and 4D). The data indicated that the combination of 5-FU and curcumin was active against MKN45 tumor xenografts and much more effective than that of 5-FU and curcumin alone.

\section{Discussion}

Gastric cancer is one of the most common malignant tumors with high morbidity and mortality. Traditional treatment is mainly based on surgery, but the prognosis is poor in patients with advanced gastric cancer. 5-FU-based chemotherapy was widely used for the treatment of gastric cancer. However, the treatment yielded poor efficacy with low response due to drug resistance and high toxicity in some patients with gastric cancer. Therefore, novel approaches with more efficacious and less toxic chemotherapeutic agents and/or combination regimens are urgently needed for the treatment of gastric cancer. Curcumin is a natural compound and showed broad antitumor activity and high safety in animal and human. Clinical trials of curcumin alone or in combination with anticancer drugs have been reported, the safety and tolerability of curcumin have been well-established in cancer patients [27-31]. Dhillon et al. reported a phase II trial of curcumin in patients with advanced pancreatic cancer [27]. The results showed that daily oral administration of $8 \mathrm{~g}$ curcumin to the patients was well tolerated and displayed biological activity in some patients. It has also been reported that the combination of curcumin and gemcitabine in patients with advanced pancreatic cancer [28]. Therefore, it may be an ideal strategy to use the combination of curcumin and 5-FU for the treatment of gastric cancer.
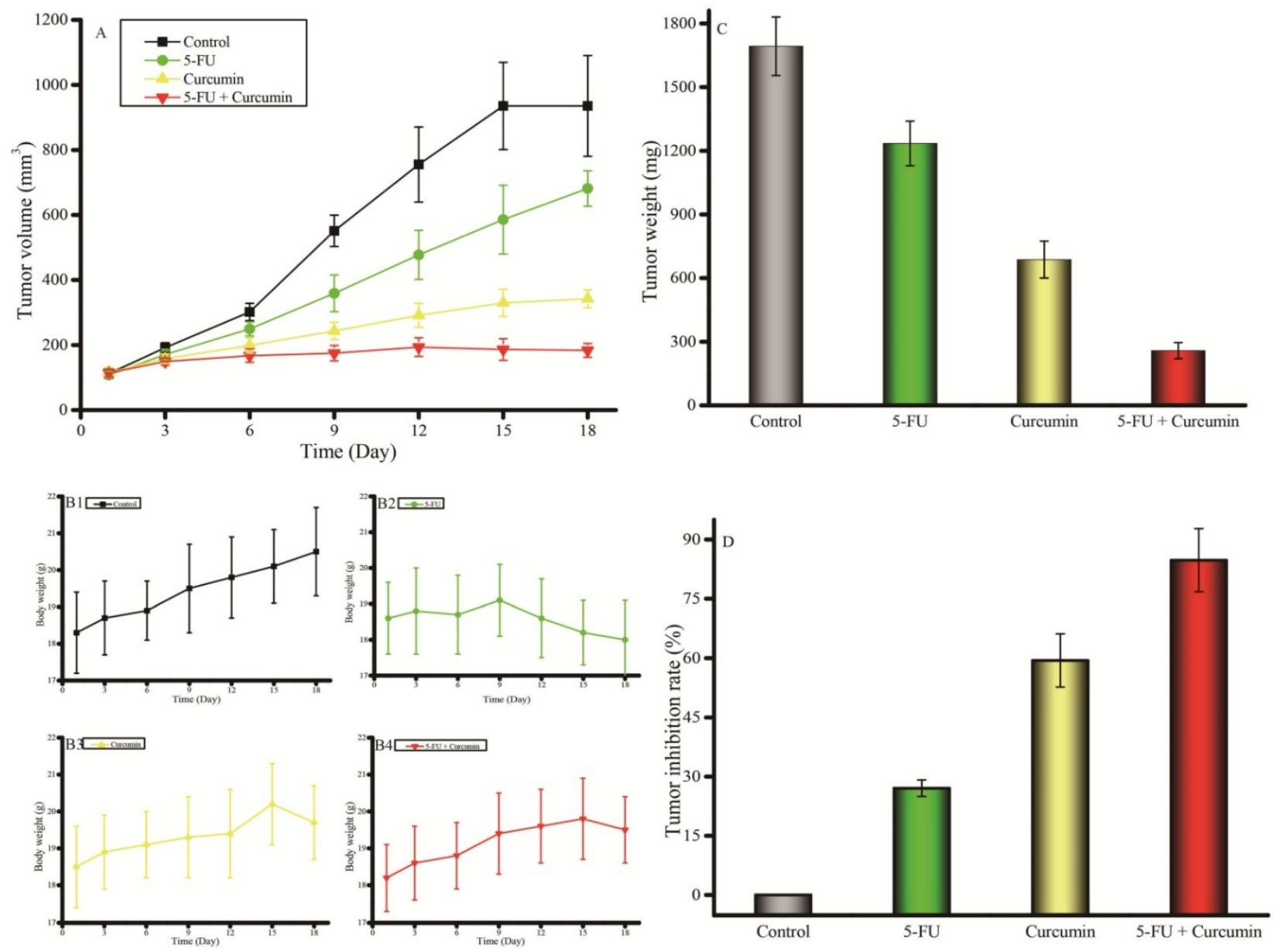

Figure 4. Antitumor efficacy and toxicity of 5-FU and curcumin alone or in combination in nude mice bearing advanced human gastric cancer MKN45 tumor xenografts in vivo. A: Kinetics of tumor volume $\left(\mathrm{mm}^{3}\right)$ in nude mice treated with 5-FU and curcumin alone or in combination; B: Kinetics of body weight change in nude mice treated with 5-FU and curcumin alone or in combination; C: Tumor weight (g) of MKN45 xenografts bearing in nude mice treated with 5-FU and curcumin alone or in combination on day 18 when the mice were humanely sacrificed; D: Tumor inhibitory rates (\%) of MKN45 xenografts bearing in nude mice treated with 5-FU and curcumin alone or in combination on day 18 , the data were calculated from actually tumor weight. Treatments were initiated 10 days after cultured MKN45 cells were inoculated subcutaneously (s.c.) in nude mice when the tumors reached to $\sim 100 \mathrm{~mm}^{3}(\mathrm{mg})$ by i.p. injection with $0.2 \mathrm{ml}$ of normal saline (as control), $5-\mathrm{FU}(52 \mathrm{mg} / \mathrm{kg})$, curcumin $(74 \mathrm{mg} / \mathrm{kg})$, or $5-\mathrm{FU}(52 \mathrm{mg} / \mathrm{kg})+\mathrm{curcumin}(74 \mathrm{mg} / \mathrm{kg})$, respectively. The mice were treated every three days (day $0,3,6,9,12$, and 15 ) for total of 6 times and were humanely sacrificed on day 18 when the tumors in the control mice reached to near $2000 \mathrm{~mm}^{3}(\mathrm{mg})$. Eight mice were used for each group and the data were presented as mean \pm SD. 
In the present study, we evaluated the cytotoxic effect of 5-FU and curcumin alone or in combination with a various concentrations of 5-FU (6.25-200.00 $\mu \mathrm{mol} / \mathrm{l})$ and curcumin $(3.125-100.00 \mu \mathrm{mol} / \mathrm{l})$ against gastric cancer MKN45 and AGS cells and compared to that of normal gastric mucosal cells GES- 1 for $48 \mathrm{~h}$ and $72 \mathrm{~h}$ drug exposure by MTT assay. The selections of the concentrations with curcumin and 5-FU in our studies was based on previous reports from the literature $[22,23]$, which showed that the inhibitory effect of curcumin was dose-dependent from 5 to 50 $\mu \mathrm{mol} / \mathrm{l}$ against AGS gastric cancer cells [22], while 100 $\mu \mathrm{mol} / 1$ of 5-FU was the optimal concentrations when combined with curcumin against colon cancer HT-29 and HCT-116 cells and no further greater cell growth inhibition could be achieved even when 5-FU concentrations were further increased up to 800 $\mu \mathrm{mol} / 1$ [23]. The results from present studies showed that both curcumin and 5-FU alone or in combination significantly inhibited the growth of gastric cancer cells MKN45 and AGS but were less effective in inhibition of normal gastric mucosal cells GES-1 in a dose- and time-dependent manner, with MKN45 cells as the more sensitive cells. Furthermore, the combination of curcumin and 5-FU showed stronger inhibitory effect on MKN45 cells than that of 5-FU and curcumin alone with 2.3- and 3.9-fold, 2.2- and 3.5-fold increased cytotoxicity for $48 \mathrm{~h}$ and $72 \mathrm{~h}$ treatment, respectively (Figure 1 \& Table 1). Our results also demonstrated that the combination of 5 -FU and curcumin has synergistic effect $(\mathrm{CI}<1)$ against gastric cancer MKN45 and AGS cells as well as normal gastric mucosal GES-1 cells, but higher concentrations of 5-FU and curcumin were required in GES-1 cells (Figure 2 \& Table 1). The data is consistent with previous studies that combination of curcumin and 5-FU exhibited synergistic cytotoxic effects against human AGS gastric cancer, K562 leukemia, and HT-29 colon cancer cells in vitro $[22,32,33]$. The data suggest that the combination of curcumin and 5-FU is more effective than each drug alone against gastric cancer MKN45 and AGS cells and it may be a useful therapeutic regimen for the treatment of gastric cancer. More importantly, the combination of curcumin and 5-FU was very effective to inhibit the growth of MKN45 tumor xenografts bearing in nude mice without increased host toxicity (body weight loss) in vivo even at suboptimal dose (Figure 4). The data validated the in vitro findings with the combination of curcumin and 5-FU.

Studies have demonstrated that COX-2 is overexpressed in gastric cancer cells compared to normal gastric mucosa and COX-2 overexpression may be related to the development and progression of gastric cancer $[10,11]$. NF-KB also plays an important role in the development of gastric cancer $[15,16]$. Therefore, COX-2 and NF-KB may be the important therapeutic targets for the treatment of gastric cancer. Studies showed that NF-KB could regulate the expression of COX-2 and curcumin may sensitize human gastric cancer AGS cells to chemotherapeutic agent via inhibiting NF-kB expression [34]. In the present study, the expressions of COX-2 and NF-kB were decreased $44.79 \%$ and $37.67 \%$ by 5 -FU and $47.17 \%$ and $48.21 \%$ by curcumin, respectively. However, the combination of 5-FU and curcumin at the same concentration but not at a lower concentration profoundly inhibited the expressions of both COX-2 and NF-kB compared to 5-FU and curcumin alone with $60.21 \%$ and $62.44 \%$ inhibition, respectively (Figure 3 ). The data indicate that the inhibition of the expressions of COX-2 and NF- $\mathrm{kB}$ proteins by the combination of 5-FU and curcumin was dose-dependent. Therefore, the greater inhibition of MKN45 cells by the combination of 5-FU and curcumin compared to single drug alone may contribute, at least in part, to the inhibition of the expressions of COX-2 and NF-KB proteins.

However, curcumin has multiple therapeutic targets in cancer therapy and can influence a variety of mechanisms associated with cancer including affecting epigenetic genes, inducing acetylation of corehistone $\mathrm{H} 3$ and $\mathrm{H} 4$, affecting miRNAs and cancer stem cells [35]. Curcumin also can influence cell proliferation, cell cycle (G2/M block), apoptosis, protein folding, proteolysis and translation $[9,22,36]$. Studies showed that curcumin may inhibit cell growth via inhibition of prostaglandin synthesis in cancer cells [34,37]. Therefore, the effect of the combination of 5-FU and curcumin on inhibition of COX-2 and NF-kB may be only one of the important mechanisms. Future studies were warrant to investigate other possible molecular targets and singling pathways associated with the anticancer activity and toxicity of the combination of 5-FU and curcumin.

\section{Conclusion}

In summary, the combination of 5-FU and curcumin showed synergistic effect with higher cytotoxic effect in vitro against gastric cancer MKN45 and AGS cells than that of each drug alone but was less effective against normal gastric mucosal GES-1 cells. More importantly, the combination of 5-FU and curcumin exhibited greater in vivo antitumor activity against gastric cancer MKN45 xenografts than 5-FU and curcumin alone without increased host toxicity. The possible mechanism may contribute to, at least in part, inhibition of the expressions of COX-2 and NF- $\mathrm{kB}$ proteins. The combination of 5-FU and curcumin may become a new option for the treatment 
of gastric cancer clinically and COX-2 and NF-KB pathways could become new therapeutic targets for gastric cancer therapy. However, it is necessary to further validate the anticancer effect of the combination of 5-FU and curcumin against gastric cancer in vitro and in vivo by morphological and immunohistochemical studied and investigate the other possible molecular targets and signaling pathways associated with anticancer effect such as human epidermal growth factor receptor (HER)-2, fibroblast growth factor receptor 2 (FGFR2), epigenetic genes, miRNAs, cell cycle and apoptosis.

\section{Acknowledgments}

This study was financially supported by the National Natural Science Foundation of China (81341124,81101678), Science and Technology Support Project of Sichuan Province (2017JQ0013), Sichuan Provincial Human Resource and Social Security Department (2016-183), the Joint Fund of Sichuan Province, Luzhou City and Southwest Medical University (14JC0134, 14ZC0026, 14ZC0066), the Joint Fund of Luzhou City and Southwest Medical University [2015LZCYD-S09 (4/8)].

\section{Competing Interests}

The authors have declared that no competing interest exists.

\section{References}

1. Romario UF, Belotti D, Pascale SD, et al. Gastric carcinoma in elderly patients. Retrospective analysis of morbidity, mortality and survival predictive factors. European Journal of Surgical Oncology. 2016; 42: S208.

2. Crew KD, Neugut AI. Epidemiology of gastric cancer. World Journal of Gastroenterology. 2006; 12: 354-62.

3. Ma HB, Wang S, Wei KF, et al. Survival status of patients with gastric cancer after radical resection: A five-year follow-up study. World Chinese Journal of Digestology. 2010; 18: 2920-4.

4. Japanese Gastric Cancer Association. Japanese gastric cancer treatment guidelines 2014 (ver. 4). Gastric Cancer. 2017; 20: 1-19.

5. Shi DB, Li XX, Zheng HT, et al. Icariin-mediated inhibition of NF-kB activity enhances the in vitro and in vivo antitumour effect of 5-fluorouracil in colorectal cancer. Cell Biochemistry and Biophysics. 2014; 69: 523-30.

6. Naksuriya O, Okonogi S, Schiffelers RM, et al. Curcumin nanoformulations: a review of pharmaceutical properties and preclinical studies and clinical data related to cancer treatment. Biomaterials. 2014; 35: 3365-83.

7. Basnet P, Skalko BN. Curcumin: an anti-inflammatory molecule from a curry spice on the path to cancer treatment. Molecules. 2011; 16: 4567-98.

8. Crețu E, Trifan A, Vasincu A, Miron A. Plant-derived anticancer agents-curcumin in cancer prevention and treatment. Revista MedicoChirugicala a Societatii De Medici Si Naturalisti Din Iasi. 2012; 116: 1223-9.

9. Cai XZ, Huang WY, Qiao $Y$, et al. Inhibitory effects of curcumin on gastric cancer cells: a proteomic study of molecular targets. Phytomedicine. 2013; 20: 495-505.

10. Park ES, Do IG, Park CK, et al. Cyclooxygenase-2 is an independent prognostic factor in gastric carcinoma patients receiving adjuvant chemotherapy and is not associated with EBV infection. Clinical Cancer Research. 2009; 15: 291-8.

11. Bekdemir $\mathrm{H}$, Tekin SB, Bilici $\mathrm{M}$, et al. COX-2 expression in gastric cancer. International Journal of Hematology \& Oncology. 2010; 32: 34-41.

12. Fu SL, Wu YL, Zhang YP, et al. Anti-cancer effects of COX-2 inhibitors and their correlation with angiogenesis and invasion in gastric cancer. World Journal of Gastroenterology. 2004; 10: 1971-4

13. Qiu ZQ, Qiu ZR. Sensitivity of gastric cancer cells to chemotherapy drugs in elderly patients and its correlation with cyclooxygenase-2 expression. Asian Pacific Journal of Cancer Prevention. 2015; 16: 3447-50.

14. Romanelli A, Pedone C, Saviano M, et al. Molecular interactions with nuclear factor B (NF-kB) transcription factors of a PNA-DNA chimera mimicking NF-kB binding sites. FEBS Journal. 2010; 268: 6066-75.
15. Rhoads MG, Kandarian SC, Pacelli F, et al. Expression of NF- $\mathrm{kB}$ and IкB proteins in skeletal muscle of gastric cancer patients. European Journal of Cancer. 2010; 46: 191-7.

16. Sohma I, Fujiwara Y, Sugita Y, et al. Parthenolide, an NF-kappaB inhibitor, suppresses tumor growth and enhances response to chemotherapy in gastric cancer. Cancer Genomics Proteomics. 2011; 8: 39-47.

17. $\mathrm{Li} \mathrm{YS}, \mathrm{Wu} \mathrm{LP}, \mathrm{Li} \mathrm{KH}$, et al. Involvement of nuclear factor kappaB (NF-kB) in the down regulation of cyclooxygenase-2 (COX-2) by genistein in gastric cancer cells. Journal of International Medical Research. 2011; 39: 2141-50.

18. Chen S, Liang Q, Xie S, et al. Curcumin based combination therapy for anti-breast cancer: from in vitro drug screening to in vivo efficacy evaluation. Frontiers of Chemical Science and Engineering. 2016; 10: 1-6.

19. Ferguson JE, Orlando RA. Curcumin reduces cytotoxicity of 5-fluorouracil treatment in human breast cancer cells. Journal of Medicinal Food. 2015; 18: 497-502.

20. Shakibaei M, Buhrmann C, Kraehe $P$, et al. Curcumin chemosensitizes 5-fluorouracil resistant MMR-deficient human colon cancer cells in high density cultures. PLoS One. 2014; 9: e85397.

21. Toden S, Okugawa $Y$, Jascur T, et al. Curcumin mediates chemosensitization to 5-fluorouracil through miRNA-induced suppression of epithelial-tomesenchymal transition in chemoresistant colorectal cancer. Carcinogenesis. 2015; 36: 355-67.

22. Koo JY, Kim HJ, Jung KO, et al. Curcumin inhibits the growth of AGS human gastric carcinoma cells in vitro and shows synergism with 5-fluorouracil. Journal of Medicinal Food. 2004; 7: 117-21.

23. Patel BB, Sengupta R, Qazi S, et al. Curcumin enhances the effects of 5 -fluorouracil and oxaliplatin in mediating growth inhibition of colon cancer cells by modulating EGFR and IGF-1R. International Journal of Cancer. 2008; 122: 267-73.

24. Chou TC, Talalay P. Quantitative analysis of dose-effect relationships: the combined effects of multiple drugs or enzyme inhibitors. Advances in Enzyme Regulation.1984; 22: 27.

25. Chou TC, Motzer RJ, Tong Y, et al. Computerized quantitation of synergism and antagonism of taxol, topotecan, and cisplatin against human teratocarcinoma cell growth: a rational approach to clinical protocol design. Journal of the National Cancer Institute. 1994; 86: 1517-24.

26. Cao S, McGuire JJ, Rustum YM. Antitumor activity of ZD1694 against human head and neck cancer in nude mice models: role of dosing schedule and plasma thymidine. Clinical Cancer Research. 1999; 5: 1925-34.

27. Dhillon N, Aggarwal BB, Newman RA, et al. Phase II trial of curcumin in patients with advanced pancreatic cancer. Clinical Cancer Research. 2008; 14: 4491-9.

28. Epelbaum R, Schaffer M, Vizel B, et al. Curcumin and gemcitabine in patients with advanced pancreatic cancer. Nutritionand Cancer. 2010; 62: 1137-41.

29. Irving GR, Iwuji CO, Morgan B, et al. Combining curcumin (C3-complex, Sabinsa) with standard care FOLFOX chemotherapy in patients with inoperable colorectal cancer (CUFOX): study protocol for a randomised control trial. Trials. 2015; 16: 110.

30. BayetRM, Kwiatkowski F, Leheurteur M, et al. Phase I dose escalation trial of docetaxel plus curcumin in patients with advanced and metastatic breast cancer. Cancer Biology \& Therapy. 2010; 9: 8-14.

31. Mahammedi $\mathrm{H}$, Planchat E, Pouget $\mathrm{M}$, et al. The new combination docetaxel, prednisone and curcumin in patients with castration-resistant prostate cancer: A pilot phase II study. Oncology. 2016; 90: 69-78.

32. Zhao $\mathrm{R}, \mathrm{Ke} \mathrm{D}, \mathrm{Xu}$ J. Synergistic antitumor effects of curcumin and 5-fluorouracil on K562 cell in vitro. Pharmacology \& Clinics of Chinese Materia Medica. 1999; 15: 15.

33. Du B, Jiang L, Xia Q, et al. Synergistic inhibitory effects of curcumin and 5 -fluorouracil on the growth of the human colon cancer cell line HT-29. Chemotherapy. 2006; 52: 23-8.

34. Lim JW, Kim H, Kim KH. Nuclear factor-KB regulates cyclooxygenase-2 expression and cell proliferation in human gastric cancer cells. Laboratory Investigation. 2001; 81: 349-60.

35. Smith AJ, Oertle J, Prato D. Multiple actions of curcumin including anticancer, anti-Inflammatory, antimicrobial and enhancement via cyclodextrin. Journal of Cancer Therapy. 2015; 6: 257-72.

36. Zhou X, Wang W, Li P, et al. Curcumin enhances the effects of 5-fluorouracil and oxaliplatin in inducing gastric cancer cell apoptosis both in vitro and in vivo. Oncology Research. 2016; 23: 29.

37. Hanif R, Qiao LS, Rigas B. Curcumin, a natural plant phenolic food additive, inhibits cell proliferation and induces cell cycle changes in colon adenocarcinoma cell lines by a prostaglandin-independent pathway. Journal of Laboratory \& Clinical Medicine. 1997; 130: 576-84. 